\title{
NyELVTANULÁS A KÖZOKTATÁSBAN
}

\author{
BAKRÓNÉ TAKÁCS GERDA \\ az Apor Vilmos Katolikus Főiskola Idegen Nyelvi, Nemzetiségi és \\ Nemzetközi Kapcsolatok Intézete főiskolai tanársegédje \\ takacs.gerda@avkf.hu
}

„Fókuszban a nyelvtanulás” címmel, Vágó Irén szerkesztésében, az Oktatáskutató és Fejlesztő Intézet gondozásában jelent meg az a nagyszabású tanulmánykötet, mely közrebocsátja az ezredforduló óta a szerzők témában végzett kutatásainak eredményeit. A szakmai alapot a szaporodó nyelvoktatás-politikai dokumentumok, a formális képzés keretében történő nyelvtanulást, -tanítást elemző szakmai publikációk, empirikus vizsgálatok szolgáltatták, többek között az országos szintü tanulói nyelvtudásmérések, a nyelvi előkészítő képzés hatásvizsgálata, az Ifjúság 2000 és 2004 nyelvtudás-kérdőív. A kötet elvitathatatlan érdeme, hogy az iskolai nyelvoktatásról kritikus, rendszerszintű elemzést ad. A szerkesztő, aki 1991-től az Iskolakultúra rovatvezetője és 1999-től az Országos Közoktatási Intézet Kutatási Központ igazgatóhelyettese, előszavában rámutat, hogy miért fontos ezzel a témával foglalkozni. Érvei között az ismert szempontok mellett az idegennyelv-oktatás irányába forduló közoktatáspolitikai törekvéseket is felsorakoztatja, továbbá szerinte azért aktuálisak a tanulmánykötet írásai, mert 2002-ig a központi oktatásirányítás nemigen próbált beavatkozni az idegennyelv-oktatás iskolai folyamataiba. Utána született meg az ágazati Nyelvoktatás-fejlesztési stratégia, elindult a Világ-Nyelv fejlesztési program és a Nyelvi előkészítő képzés (NYEK), majd nagyszabású oktatási programcsomag-fejlesztés kezdődött, $\mathrm{s}$ támogatta mindezt a bevezetésre került kétszintü érettségi vizsga. A fejlődés jelei egy összehangoltabb, hatékonyabb, költségtakarékosabb iskolai nyelvoktatás irányába mutatnak, annak ellenére, hogy az iskolai nyelvoktatás müködését a decentralizált irányítási rendszer, a laza szabályozók és a puha költségvetési korlátok miatt napjainkban is elsősorban a helyi, intézményi és iskolahasználói érdekek határozzák meg. Vágó Irén pozitívan értékeli a pedagógusbérek emelésének hatását is, mivel így gyakorlatilag megszünt a képzett nyelvtanárok hiánya, és fluktuációjuk az iskolákban.

A kötet első tanulmánya a „Stratégiától a kistérségi együttmüködésekig - az idegennyelv-oktatás koordinációja" címmel Balázs Éva tollából származik. Balázs Éva az Oktatáskutató és Fejlesztő Intézet Kutatási Csoportjának főmunkatársa, a közoktatási tervezés rendszerének szakértője. Tanulmányában a nemzeti alaptantervtől indul ki, s a hazai nyelvoktatáspolitikai állomások mellett, egyéb, a témához lazábban vagy nem közvetlenül kapcsolódó tényezőkre tér ki (PISA felmérések, az 
alkalmazás-központú tudásfogalom központba kerülése, alapkompetenciák birtoklásának kérdése), majd a nemzetközi kontextust vizsgálja. A nyelvtanulás oktatáspolitikai agendára történő felkerüléséhez jelentős nemzetközi inputot adott az, hogy az Európa Tanács 2001-et a Nyelvek Európai Évének nyilvánította. Ennek keretében átfogó elemzés készült az európai országok idegennyelv-oktatásáról. ${ }^{1}$ Az uniós csatlakozáshoz egyre közelebb kerülő Magyarországon a fentiek az aktivitás fokozódásához vezettek. Az idegennyelv-oktatás fejlesztése kiemelten jelent meg az EU ún. lisszaboni programjában is, amelynek fő célkitüzése, hogy az európai térség 2010-re a világ legversenyképesebb régiójává váljon. Magyarország is bekapcsolódott a 2002-ben alakult „Oktatás és képzés 2010” program nyelvoktatással foglalkozó bizottságába. A nyelvoktatás hazai stratégiájának elkészítése, s e stratégia megvalósításához számos eszköz hozzárendelése végül a 2002-ben hivatalba lépett kormányhoz köthető, amely 2002 decemberében jóváhagyta a „Világ-Nyelv” stratégiát. ${ }^{2}$ A tanulmány a program közoktatási részére fókuszál két szempontból: az első az állam részéről nyújtott kínálat elemzése a stratégiában meghatározott célkitủzések kontextusában, a másik szempont pedig az állam és a programokban megszólítottak közötti viszony. A szerző részletesen elemzi az egyes programcsomagok (NYEK, „Nyelv+számítógép”, „Forrás”, „Nyelv+szakma felsőfokon”, „Éleszto””, „Előre fuss", kétszintü érettségi) hatását. Hangsúlyozza, hogy ezen programok megvalósítása nem jöhetett volna létre, ha a helyi, kistérségi és megyei tervezés és az idegennyelv-oktatás stratégiája között nem alakul ki kapcsolat. Ennek pontos megértéséhez a szerző egy külön fejezetet szentelt „A területi közoktatás-tervezésről, dióhéjban" címmel.

Balázs Éva nevéhez köthető a 2001/2002-2005/2006. tanévek között az Országos Közoktatási intézet Kutatási központjában az első Nemzeti Fejlesztési Terv Humánerőforrás-fejlesztési Operatív Programja keretében végzett kutatás, melyben azt vizsgálták, hogyan jelenik meg az érvényes megyei közoktatási tervekben az idegennyelv-oktatás. A kutatás eredménye megdöbbentő: explicit módon sehol sem jelenik meg az idegennyelv-oktatás, sem annak eredményessége, hatékonysága. Ugyancsak meglepőek azok a következtetések, melyeket a szerző egy 2006-os kérdő́ves vizsgálat alapján vont le: a kistérségek mindössze 30\%-ában jöttek létre munkaközösségek az idegennyelv-oktatás koordinálására, de reménykedésre ad okot az, hogy a munkaközösségeket nem müködtető kistérségekben is vannak kooperációk (egymás iskoláinak idegennyelv-óráinak látogatása, tanártovábbképzés, egyeztetés a tankönyvválasztásban...) Tanulmányának végén a mellékletben tekinthetö meg a kérdőív, melyet a szerző kutatásaihoz felhasznált.

Nikolov Marianne a Pécsi Tudományegyetem egyetemi tanára. Kutatási területe: alkalmazott nyelvészet, nyelvpedagógia, idegen nyelvek tanulása, tanítása, nyelv-

\footnotetext{
${ }^{1}$ Profile of foreign language teaching in shoolss in Europe (2001): Eurydice, Brussels

2 [online:] \{www.om.hu/main.php?folderID $=413 \&$ articleID $=2043 \&$ ctag $=$ articlelist $\&$ iid $=1\}$
} 
tudás mérése és értékelése, osztálytermi kutatások, egyéni különbségek. A „Fókuszban a nyelvtanulás” címü tanulmánykötetben „A magyarországi nyelvoktatás-fejlesztési politika - nyelvoktatásunk a nemzetközi trendek tükrében" címmel tette közzé a legutóbbi évtized nyelvpolitikájában látható célkitüzéseket, illetve azok európai és hazai megvalósulását. Rámutat azokra a területekre, amelyek az elmúlt évtized során a kitörési pontokat jelentették. Megállapítja, hogy a közelmúlt hazai nyelvpolitikájának alapelvei és célkitüzései egybeesnek az európai trendekkel. Ennek következtében számos kézzelfogható eredményt felmutató innovatív program múködik jelenleg a közoktatásban. A tanulmány első része áttekinti a központi nyelvpedagógiai fejlesztések hátterét, a nyelvtanulás prioritásait és helyzetét. Beszámol a nyelvtudási szintek átfogó értékelését célul tüző vizsgálatok tapasztalatairól, a nyelvtanulás folyamatával és eredményével összefüggő tényezők (nyelvválasztás, esélyegyenlöség, motiváció, a diákok céljai, korai nyelvtanulás, folytonosság, átmenet, egymásra épülés, óraszámok, iskolán kívüli nyelvtanulás) szerepéről, összefüggéseiről. Kiemelendő ebből a fejezetből az esélyegyenlőség kérdése, hiszen közismert, hogy közoktatásunk gyenge pontja a hozott hátrányok kompenzálása. A tanulmány második része az Oktatási Minisztérium nyelvoktatás-fejlesztési stratégiájában megfogalmazott alapelveket és célokat, illetve azok megvalósulását értékeli, döntően a nyelvi előkészítő évfolyamokra fókuszálva. Összegzésében a szerző kedvező irányultságúaknak véli a folyamatokat, de felhívja a figyelmet a tennivalókra. Megoldandó problémaként tünteti fel az esélyegyenlőség biztosítását. Örömmel üdvözli a számos innovatív projektet, de figyelmeztet a lassú fejlődésre is. A helyzet megváltoztatására szerinte hatékonyabb pedagógusképzésre és folyamatos tanártovábbképzésre lenne szükség. Az idegennyelv-oktatás eredményességét nagymértékben rontja a korai szelekció, a differenciált nyelvtanítási eljárások hiánya, a nyelvi programok túlzott sokfélesége és a nem megfelelö átmenet. Nikolov Marianne optimista abban a tekintetben, hogy a Világ-Nyelv program folytatódik, az idegennyelv-tanulás várhatóan továbbra is az érdeklődés középpontjában marad. A szerző szerint meg kell teremteni a tartalom alapú oktatás feltételeit, meg kell valósítani a kereszttantervi integrációt, a nyelvtanárokat fel kell készíteni célnyelvi órák megtartására, továbbá biztosítani kell a felmenő rendszert. Felhívja a figyelmet a még kutatásra váró területekre, mint például az alsó tagozatos nyelvi foglalkozások tevékenységeinek elemzése a tantervi célok tükrében, évfolyamonkénti egymásra épültség az idegennyelvi készségek tekintetében, a nyelvtanulási motiváció alakulása, folytonosság a módszerekben, az érettségi vizsgák monitorozása, és egy standardizált feladatbank létrehozása, amely hosszú távra megbízható visszajelzést biztosítana a közoktatás szereplöi számára.

A tanulmánykötetben Einhorn Ágnes az Oktatáskutató és Fejlesztő Intézet Követelmény- és Vizsgafejlesztő Központ tudományos főmunkatársa „Az idegen nyelvi érettségi vizsga reformja" címmel összegzi a kétszintủ érettségi vizsgák tapasztalatait, hatását a napi tanítási gyakorlatban. Meghatározó újdonsága, hogy ilyen rész- 
letességü vizsgaleírás eddig sem az érettségihez, sem a felvételi vizsgához nem készült Magyarországon. A reform másik jelentős eredménye, hogy az idegen nyelvekből készségmérő vizsga lépett a korábbi, tradicionálisabb helyére. Mivel az új rendszerben mindegyik kommunikatív készség (olvasás, hallás, írás, beszéd) mérésre kerül, megkerülhetetlenné vált a készségfejlesztésen alapuló nyelvtanítás. Erre ösztönöz az is, hogy az emelt szinten legalább 60\%-os teljesítés mellett a vizsgázó államilag elismert nyelvvizsga-bizonyítványt kap, amely a felsőoktatási felvételi eljárásban pluszpontokat jelent. A tanulmány szerzője külön figyelmet fordít a tantárgyi mérés kérdésére, és javaslatot tesz annak tanító- és tanárképzésbe történő kooptálására. Einhorn szerint minden nehézség ellenére az új vizsgarendszer bevezetése a középiskolai idegennyelv-tanítás hatékonyságának megerősödéséhez, modernizációjához vezethet, és ez a tendencia hosszú távon kedvezőleg fog hatni az általános iskolákra is. A szerző értékes munkát végzett, mikor megjelölte a szemléletváltozás összetevőit, okait, eredményeit, következményeit. Részletesen leírja, hogyan hatottak a nemzetközi törekvések a vizsgafejlesztésre, miként kerültek részletes leírásra a vizsgadokumentumokban az egyes készségszintek. Bemutatja, milyen problémák jelentek meg a vizsgafejlesztés során (például a vizsgaszintek objektív leírása), és milyen kompromisszumokat kellett a vizsgafejlesztőknek kötniük. Táblázatos és szövegesen kifejtett formában is közrebocsátja az empirikus adatait, ami az áttekinthetőséget javítja. Megismerhetjük az angol, német közép és emelt szintü vizsga teljesítményadatait is, s részletesen elemzi az érettségi és a nyelvvizsga eredményeinek összefüggéseit. Külön fejezetet szentel a vizsgareform egyik jelentős szakmai eredményének, az új értékelési kultúra kialakulásának. Megismerhetjük az egyes feladattípusok értékelésének alapelveit, lehetséges módjait.

Az utolsó fejezetben mintegy összegzésként egy másik tanulmányában a várható visszahatásokkal ismerteti meg Einhorn Ágnes az olvasókat. Úgy véli, hogy a vizsga bevezetése után a tanári munka középpontjába az új vizsga tartalmi része kerül, és iskolai szinten szakmapolitikai megközelítések helyett inkább a szakmapedagógiai megközelítések lesznek jellemzőek. Sajnálatát fejezi ki, hogy a tanárképzési rendszerben csak a vizsgáztatók felkészítésére volt mód, ezért fontosnak tartaná, hogy bekerüljenek a nyelvtanárképzése az új érettségihez kapcsolódó dokumentumok, és azok elemzése is. A jelenlegi helyzetet útkeresésként aposztrofálja. Örvendetesnek találja, hogy a tankönyvpiac gyorsan és hatékonyan reagált, tömegesen jelentek meg a feladatgyüjtemények, melyek az érettségi vizsga feladattípusaihoz hasonló feladatokat tartalmaznak. Nyilvánvalónak tartja, hogy a vizsgaeredmények és a vizsgáztatás során adódó tapasztalatok alapján az érettségi vizsga bizonyos elemeit módosítani kell majd, tehát szükség lesz változásokra mind a vizsgaszabályozás, mind a tantárgyi vizsgaleírások esetén. A folyamat jelenlegi állapotában megállapítható, hogy a középiskola képes a tanulókat felkészíteni a megváltozott vizsgára, bár a felkészítő munka tervezésében és alakításában is nagyon sok a teendő még. 
A kötet negyedik tanulmányát Imre Anna az Oktatáskutató és Fejlesztő Intézet Kutatási Központjának tudományos főmunkatársa „Nyelvoktatás, nyelvtanulás, nyelvtudás a középfokú oktatásban" címmel jelentette meg. Imre Anna abból indul ki, hogy Magyarországon több mint másfél évtizeddel a rendszerváltás után is nagy gond a megfelelő nyelvtudás hiánya. Nemzetközi viszonylatban még mindig alacsony az idegen nyelven kommunikálni képes személyek aránya a népességen belül. ${ }^{3}$ Bár az elmaradás ellenére a fejlődés komolynak mondható, ha az induló helyzethez viszonyítunk. ${ }^{4} \mathrm{Az}$ idegennyelv-oktatás expanziója az iskolai nyelvtanításban 1989 után, az orosz kötelező voltának eltörlése után tudott megindulni, de már korábban, a nyolcvanas évek második felében is érzékelhető volt a nyelviskolák piacán a társadalmi igények erősödése. A 2000-es évek elejéig a közoktatásban megnyíló lehetőségek rövid idő alatt igen látványos átalakulást eredményeztek. A fejlődés fö hatóerejét a társadalmi igények és a hozzájuk kapcsolódó intézményi érdekek jelentették, de a kedvező folyamatokat a jogszabályi változások és a különböző időszakok más-más területeket érintő oktatáspolitikai intézkedései is nagyban segítették. Ilyenek voltak például a kéttannyelvü iskolák szerveződése a nyolcvanas évektöl, a szakiskolai nyelvoktatás kiterjedése a kilencvenes évek végétől, a Tempus Közalapítvány Világ-Nyelv programja, a nyelvvizsga tartósan érvényesülő beszámítása a felvételi pontszámokba, a nyelvtanulás költségeinek adókedvezménnyel történő támogatása, továbbá a nyelvi előkészítő évfolyamok indítása. A kilencvenes évek elejétől eltelt időszakban a hazai nyelvoktatás terén hasonló tendenciák körvonalazódtak, mint az EU-ban: a tankötelezettség ideje alatt idegen nyelvet tanulók száma az EU átlagában nőtt, s az utóbbi 10-15 évben a nyelvoktatás időtartama az iskolarendszeren belül több országban hosszabbá vált, az oktatás kezdetének korábbra tevődése miatt. A tanult nyelvek közül első helyen a legnagyobb „kommunikációs potenciállal” rendelkező nyelv, az angol áll, ezt követi a német vagy a francia. A szerző megállapítja, hogy a tanulólétszám gyors csökkenése idején a munkaerőpiacra igen érzékenyen reagáló nyelvoktatás egyfelöl az intézmények között a diákokért folyó verseny egyik legfontosabb eszközévé vált, másfelöl területileg igen eltérő mintázatot alakított ki az oktatott nyelvek szerkezetét illetően. A nyelvoktatás hazai helyzetét, tapasztalatait és problémáit több elemzés, empirikus vizsgálat érintette az elmúlt másfél évtizedben (Csapó, 2001; Imre, 2000; Vágó, 2000; Vámos, 1998). A tanulmány leginkább Vágó Irén „Az idegennyelv-tanulási utak" címü kutatásának keretében készült 2004-es adatfelvételre támaszkodik, amely döntően egy a 9. évfolyamon történő teljes körủ tanulói adatfelvételre épült, s elsősorban a nyelvoktatás feltételeinek alakulásával, illetve a tanulók nyelvtanulási esélyeivel összefüggő egyes kérdéseket érinti. A szerző bizonyítja, hogy a kö-

\footnotetext{
${ }^{3}$ 2005-ben az EU felmérése szerint: az EU 25 tagállamában a 15 évnél idősebb kérdezettek átlagosan 50\%-a nyilatkozta, hogy beszél valamilyen idegen nyelven, Magyarországon csak 29\%-a.

${ }^{4}$ 1990-ben a népszámlálási adatok szerint mindössze 9,1\% volt az idegen nyelven beszélni képes személyek száma a lakosságon belül.
} 
zépfokon oktatott idegen nyelvek egyenlőtlen pozíciója a nyelvet tanulók helyzetében, tanulási útjaiban és későbbi nyelvtudásában is megragadható, ezért kísérli meg a formális oktatási rendszeren belüli, illetve azon kívüli különböző tanulási utak követését. A tanulmány első részében a kilencvenes évekre jellemző fontosabb menynyiségi, átstrukturálódási változásokat tekinti át kronologikusan és nyelvenként, a második részben a jelenlegi helyzetről fest képet azáltal, hogy bemutatja a nyelvtanítás, -tanulás feltételrendszerét, és elemzi a tényleges tanulási utakat, a nyelvválasztástól az iskolarendszeren kívüli nyelvtanuláson át az önálló nyelvtanulásig. A harmadik fejezetben az „Ifjúság 2000, 2004” elnevezésű kutatásokból származó adatok alapján áttekinti a kimeneti oldalon történt változásokat. Nagy érdeme a tanulmánynak, hogy nemcsak mennyiségi szempontból tanulmányozza a középfokú oktatásban oktatott idegen nyelveket, hanem kitér a nyelvi csoportok szervezésének alapelveire, a nyelvtanárok végzettségére, a nyelvből szerzett érdemjegyekre. Öszszegzésében a szerző megállapítja, hogy a nyelvoktatás mégsem egészen piaci, szülői igények szerint alakul, jelentős szerepe volt és van az oktatási rendszeren belül az intézményi kínálat sajátosságainak is. A kimeneti oldalon megfigyelhető tendenciák, a saját bevallásuk szerint nyelvtudással, nyelvvizsgával bíró fiatalok aránya jelentős mértékü növekedést, javulást mutat. A középfokról kilépő fiatalok nyelvismerete láthatóan leképezi és megörzi a nyelvoktatásban megfigyelhető programok és régiók közötti különbségeket mind mennyiségi, mind szerkezeti sajátosságaiban.

A tanulmánykötet utolsó, mintegy összegző tanulmányát maga a szerkesztő, Vágó Irén készítette „Nyelvtanulási utak Magyarországon” címmel. Tanulmányát a szerzőnő nemzetközi, történeti kitekintéssel kezdi, melyből megismerhetjük Magyarország lakosságának nyelvtudási adatait, az eredmények okait, közben a jó nemzetközi gyakorlatokkal is (autentikus szövegek beépítése, filmfeliratozás szinkronizálás helyett...) megismerteti az olvasót. A tanulmány magja „Az idegennyelvi-tanulási utak" címü kutatás, melynek céljai között szerepelt az egyes tanulók idegennyelv-tanulási lehetőségeinek megismerése, a közoktatási rendszer nyelvi kínálatának feltérképezése, nyelvváltás/tanárváltás gyakoriságának előfordulása, az általános és középiskola közötti átmenet kérdése és a nyelvtanulók motivációi. Az adatok elemzésével a szerző képet fest az 1-9. évfolyam nyelvi kínálatáról, a korai nyelvoktatásról ${ }^{5}$, a nyelvtanulási utak hosszúságáról, azaz a nyelvtanulásra fordított tanévek számáról a középfokú intézmények első évfolyamára belépő tanulóknál. Külön alfejezetben vizsgálja a szerző a nyelvtanulás szempontjából hátrányos helyzetü csoportokat, hisz jelenleg ennek leküzdése a közoktatás egyik kiemelt feladata. Megállapítja, hogy a tanári fluktuáció, az alap és középfok illeszkedési nehézségei mind a nyelvtanulás hatékonyságát csökkentik. Nem okozott nagy meglepetést a kérdőív adatainak feldolgozásánál, hogy a diákok elsősorban az angolt, majd a németet és franciát választják tanulandó nyelvként, hisz ez európai tendencia is. A maga

\footnotetext{
${ }^{5}$ Nem összetévesztendő a korai nyelvelsajátítással
} 
nemében ritka, hogy diákokat az idegennyelv-tanulással kapcsolatos terveikről kérdezik. Ebben a tanulmányban táblázatos és szöveges formában is megismerkedhetünk a nyelvtanulási célokkal és gyakoriságukkal. A 9-10-es diákok 45,3\%-a érettségizni/nyelvvizsgázni szeretne az első idegen nyelvéből, 16\%-ukat a jó érdemjegy motiválja, 10,9\%-uk felsőfokú végzettséget szeretne szerezni az adott nyelvből. A válaszadók majdnem egyharmada a munkájában kívánja idegennyelv-tudását hasznosítani, vagy külföldön vállalna munkát. Csaknem egynegyede a válaszadóknak azért tanul idegen nyelvet, hogy a mindennapokban elboldoguljon. Örvendetes tény, hogy csak 3,8\% utasítja el a nyelvtanulást, és hagyná abba, amint lehet. Vágó Irén foglalkozik az iskolán kívüli nyelvtanulással abból a szempontból, hogy melyik társadalmi réteg gyermekei élnek elsősorban ezzel a lehetőséggel. Az iskolai nyelvoktatás viszonylagos eredménytelenségének legföbb okaként még 2003-ban is a nyelvórák alacsony számát jelölték meg. A kutatás azonban cáfolja ezt. A gimnáziumokban 4,7; a szakközépiskolákban 4,2 az első idegen nyelv átlagos heti óraszáma. A tanulmányban ezután a közoktatásban kapott összes nyelvóra átlagáról olvashatunk a különböző tanulói csoportokban.,Az idegennyelv-tanulási utak” címü kutatás legnagyobb érdeme, hogy általa elöször sikerült rekonstruálni egy adott évfolyamba tartozó valamennyi diák nyelvtanulási útját, bemutatva, hogy az egyes gyerekek és tanulócsoportok az 1-12. évfolyamig összesen milyen óraszámot fordíthattak nyelvtanulásra az iskolában. A tanulmány egyértelmüen bizonyítja, hogy bár az állam másfél évtizede rendkívül jelentős erőforrásokat biztosít a közoktatásban folyó nyelvoktatásra, de ez csak csekély mértékben váltotta be a hozzáfüzött reményeket. A tanulmány szerzője ennek okait hozzáférési, esélyegyenlőségi és hatékonysági problémákra eredezteti vissza.

A tanulmánykötetet fontos irodalomként javasoljuk a nyelvtanár szakos hallgatók képzésében, de nagy haszonnal forgathatják a téma iránt érdeklődők is.

Vágó Irén (szerk.): Fókuszban a nyelvtanulás. Oktatáskutató és Fejlesztő Intézet, Budapest, 2007. 179 oldal

\section{Irodalom}

Csapó Benő (2001): A nyelvtanulást és nyelvtudást befolyásoló tényezők. Iskolakultúra, 8. sz. 25-36.

Imre Anna (2000): Idegennyelv-oktatás a 90-es években. Educatio, 4. sz. 701-716.

Vágó Irén (2000): Idegennyelv-oktatás fö tendenciái a 80-as és 90-es években. Educatio, 4. sz. 668-690.

Vámos Ágnes (1993): Magyarország tannyelvi atlasza. Keraban Kiadó, Budapest 